\title{
EFFECT OF THE MATRIX AND FILLER PHASE COMPOSITION ON THE EROSION RESISTANCE OF CARBON-CARBON COMPOSITE MATERIALS FABRICATED BY THE GAS-PHASE INFILTRATION METHOD
}

\author{
Yu.A. Gribanov, I.V. Gurin, V.V. Gujda, Yu.V. Gujda \\ National Science Center "Kharkov Institute of Physics and Technology", \\ Kharkiv, Ukraine \\ E-mail: igor@kipt.kharkov.ua; phone/fax+38(057)349-10-61
}

\begin{abstract}
The erosion factor of the matrix and filler phase composition having influence on the C-C composite resistance has been shown. The main mechanisms of such an effect are determined and the steps of improving the functional characteristics of composites are determined. It is assumed that the erosion and sublimation resistance of C-C composites, obtained by the gas-phase infiltration method using the radially-moving zone of pyrolysis, is due, first of all, to a highly-ordered crystalline pyrocarbon matrix. It is shown that the $\mathrm{C}$-C composites have a unique temperature resistance and workability at high temperatures.
\end{abstract}

PACS: 621.762

\section{INTRODUCTION}

Carbon-carbon composite materials (C/C), obtained by the thermogradient gas-phase infiltration using the radially-moving pyrolysis zone, have: high temperature sublimation; high mechanical strength at temperatures up to $2.800{ }^{\circ} \mathrm{C}$; high resistance to thermal stresses; chemical inertness; low density; high corrosion resistance and a number of other characteristics $[1,2]$. The advantages of $\mathrm{C}-\mathrm{C}$ composites, compared to the alternative high-temperature structural materials, promote their use in the critical elements of aerospace engineering. For example, in a rocket solid-fuel engine (RSFE) the gas flow temperature reaches $2500{ }^{\circ} \mathrm{C}$ or more, provided that solid fuel combustion products contain abrasive particles. The ablation and erosion wear of the material in the RSFE critical cross-section is accompanied by decreased engine thrust, increased fuel consumption and can lead to accidents. Currently, $\mathrm{C}-\mathrm{C}$ composites are commonly used for fabrication of the nozzles of rockets returning from space, wing edges and flaps of spacecraft, inserts, etc. [3].

The purpose of this study is to evaluate the resistance of $\mathrm{C}-\mathrm{C}$ composite under conditions of erosion and sublimation wear of the structural material. To achieve this purpose, a series of tests on different composite materials were carried out to determine the erosion and sublimation rate under conditions of the stand placed at the Pavlograd Chemical Plant (SE RIC PCP).

\section{STUDY ON THE EROSION RESISTANCE OF PYROCARBON-BONDED COMPOSITES}

For investigations a series of critical cross-section inserts were made from various materials. The appearance of the insert is presented in Fig. 1.

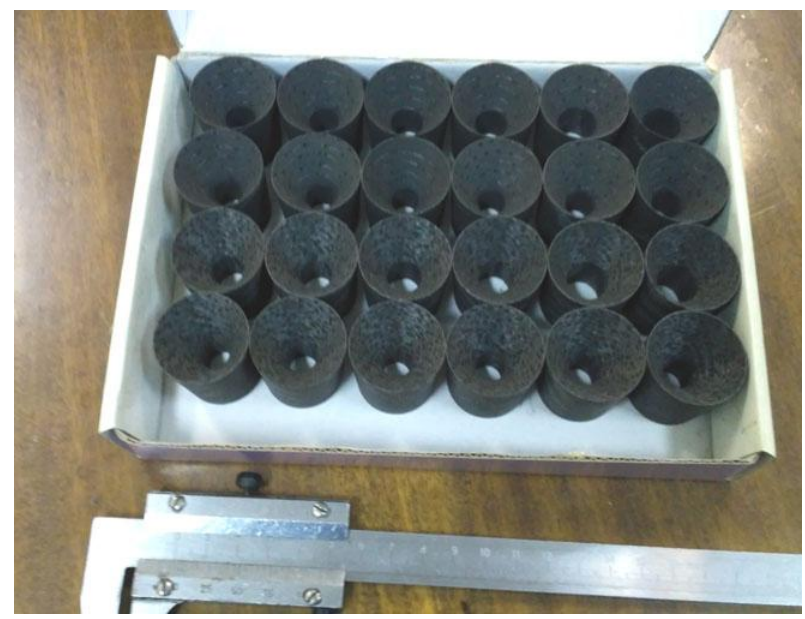

Fig.1. Appearance of the model insert of a critical cross-section for investigations under conditions of the SE RIC PCP

At the first stage, the inserts fabricated from pyrocarbon-bonded graphite (GSP) were tested (4). In fact, GSP is the carbon-carbon composite containing the powder of industrial-grade graphite, or powder with a high content of pyrocarbon, which is obtained by mechanical processing of $\mathrm{C}-\mathrm{C}$ composite material. Depending on the pyrocarbon content, materials GSP50, GSP-75, GSP-90 differs by the figure indicating the percentage of the pyrocarbon matrix in the composite, respectively.

By its characteristics, GSP is similar to the highquality industrial graphites, but significantly exceeds their strength and resistance to burnout. GSP-75 material was used to conduct experiments on the stand.

The data on the burnout of inserts fabricated from different carbon/carbon composites are given in Table.

Data on the burnout of inserts fabricated from different carbon-carbon composites

\begin{tabular}{|l|c|c|c|}
\hline \multicolumn{1}{|c|}{ Material } & GSP & TNC & "Suvius" \\
\hline Critical diameter before testing, $\mathrm{mm}$ & 11 & 11 & 11 \\
\hline $\begin{array}{l}\text { Critical diameter after testing, } \mathrm{mm} \\
\text { Input - output cross-section (average) }\end{array}$ & $11.32 \ldots 12.67(12)$ & $11.21 \ldots 11.38(11.30)$ & $11.16 \ldots 11.95(11.56)$ \\
\hline Mass loss, $\Delta \mathrm{m} / \mathrm{m}, \%$ & 1.08 & 4.60 & 4.37 \\
\hline
\end{tabular}


Fig. 2 shows the appearance of inserts tested on the stand. As can be seen from the figure, the GSP insert has preserved its integrity, but in the entry area the thin walls of GSP material did not withstood the load that resulted in material cracking. In addition, in some experiments a nonuniform critical cross-section heating was observed. However, it should be noted that the GSP insert had a minimum loss of mass.

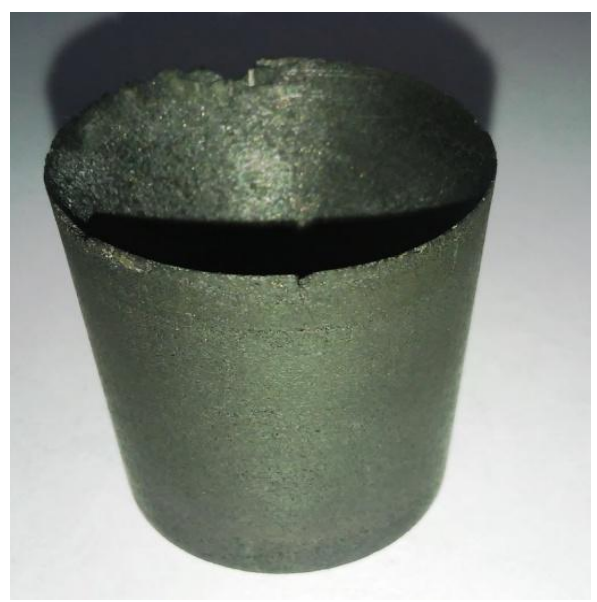

Fig. 2. Appearance of the GSP inserts after testing on the stand

In subsequent experiments the tests were carried out on the stand with inserts fabricated from $\mathrm{C}-\mathrm{C}$ composites of brands TNC and Suvius. The TNC C/C insert is a composite with a winding structure of carbon viscose tissue bounded by $\mathrm{PyC}$ using the thermogradient gas-phase infiltration technique. The Suvius $\mathrm{C} / \mathrm{C}$ insert is a composite with a structure wound on the mandrel where the carbon fiber layer alternates with carbon felt. The average density of preforms is $0.62 \ldots 0.64 \mathrm{~g} / \mathrm{cm}^{3}$.

To fabricate inserts the material was designed so that its direct contact with the gas jet maximally took place in the zone of the layer with an increased content of the pyrocarbon matrix. The inserts of both $\mathrm{C} / \mathrm{C}$ brands have preserved their integrity after testing. The appearance of inserts after testing is shown in Fig. 3.

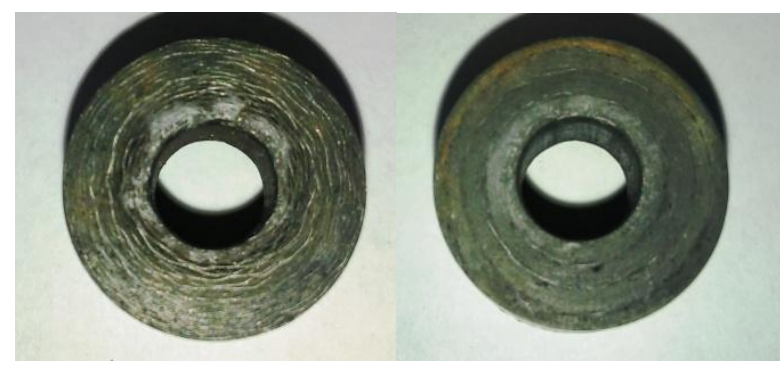

Fig. 3. Appearance of the inserts after testing on the stand (on the left - THC C/C, on the right - "Suvius" $\mathrm{C} / \mathrm{C}$ )

As is seen from the given data, both the TNC and "Suvius" composites have withstood the test conditions (pressure of about 100 atm, high temperature, erosion wear). However, the insert made from the "Suvius" composites shows a smaller weight loss, although this $\mathrm{C}-\mathrm{C}$ composite material has a noticeably greater nozzle "blur" (erosion) on the rear face.
The results of tests under harsher conditions are presented in Fig. 4.

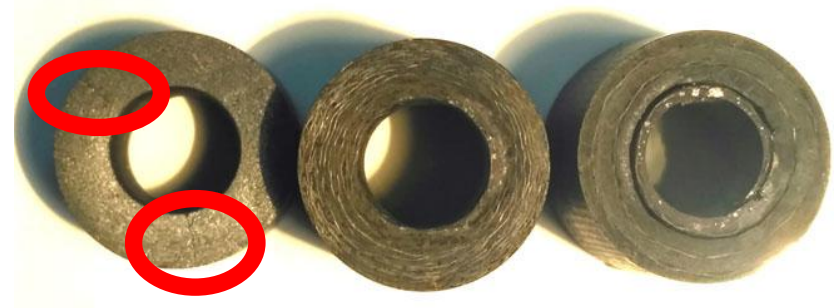

Fig. 4. Appearance of the inserts after testing (on the left-GSP, in the middle - TNC C/C, on the right - "Suvius"

As can be seen from Fig. 4, when the load on the insert increases, the GSP cracking occurs. The TNC and "Suvius" composites have withstood the tests without destruction. However, in the "Suvius" material the degree of burnout of layers having different matrix content is very different that correlates well with the data on the composite resistance to oxidation reported in [5]. However, the burnout of TNC composite material, having a higher burnout degree, occurs more uniformly.

\section{STUDY ON THE EROSION RESISTANCE OF C-C COMPOSITES WITH PROTECTIVE COATING}

The C-C composites, having high physicalmechanical properties, show a relatively low corrosion resistance at temperature above $500{ }^{\circ} \mathrm{C}$. In this regard, there is a need to protect $\mathrm{C}-\mathrm{C}$ composites from the hightemperature corrosion. The attempt to protect graphite and $\mathrm{C}-\mathrm{C}$ composites from oxidation using protective coatings is associated with overcoming a number of difficulties related to their low temperature linear expansion coefficient (TLEC), structure inhomogeneity, high porosity and volatility of oxides. At high operating temperatures in the products made from $\mathrm{C}$ - $\mathrm{C}$ composites with a protective coating a gas release is observed that leads to the destruction of the composite surface layer.

The refractory metals and their compounds used as components of the protective layer have TLEC which significantly differs from that of carbon compositions and, as a result, there is a problem of coating adhesion to the base [6]. In connection with the above, there is a need to conduct tests on the erosion resistance of C-C composites with a protective coating.

The erosion resistance of $\mathrm{C}-\mathrm{C}$ composites with a protective coating was investigated on the special test stand in the SE "Yuzhnoye Design Office" under conditions of liquid-fuel engine operation simulation.

The appearance of the test stand is presented in Fig. 5.

To carry out the tests on the corrosion resistance of the TNC composite with a deposited protective coating we have prepared the $\mathrm{C}-\mathrm{C}$ composite samples. The sample has been coated with a slurry layer of powder mixture $(\mathrm{Si}+\mathrm{Zr}+\mathrm{B}+\mathrm{Hf}+\mathrm{Mo})$ followed by boron siliconizing at temperature of $1300{ }^{\circ} \mathrm{C}$ for $18 \mathrm{~h}$. The thickness of the formed heat-resistant layer was about $160 \mu \mathrm{m}$, and the specific increase of mass was $114 \mathrm{mg} / \mathrm{cm}^{2}$. 
During the experiment, the sample tested on the stand was heated nonuniformly.

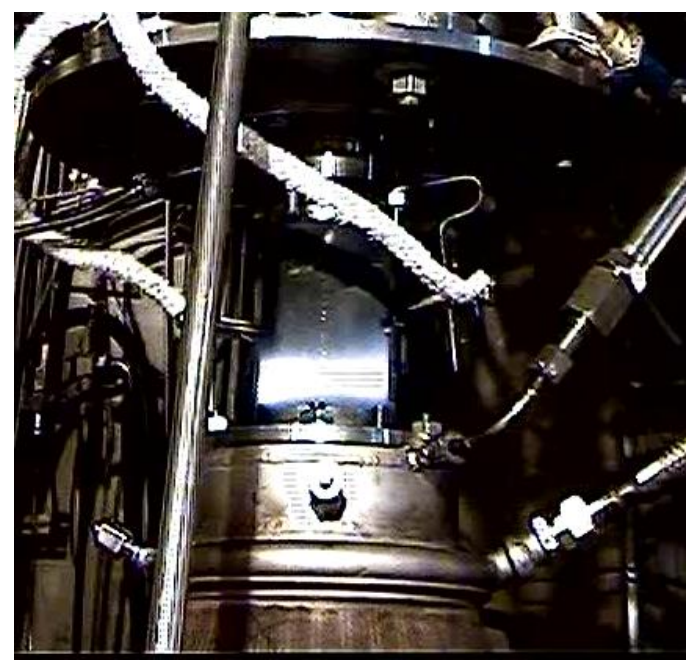

Fig. 5. Appearance of the stand for testing $C-C$ composites with protective coating under conditions of liquid-fuel engine operation simulation

There was a high-temperature gas jet which formed a critical cross-section overheating leading to the nonuniform through burnout of the sample in this area.

Due to a critical drop of the test stand parameters, the experiment was stopped. The appearance of the sample after the experiment stopping is shown in Fig. 6.
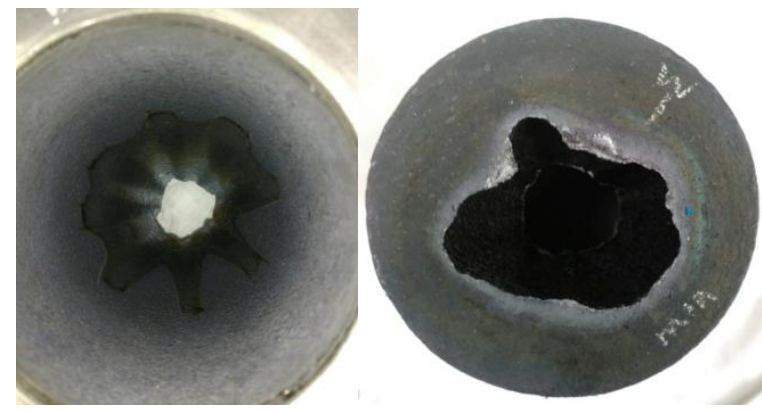

Fig. 6. Appearance of the sample from the $C$-C composite with a protective layer in the critical-section overheating zone

Studies have shown that there is a significant burnout of irregular forms in the critical cross-section zone. This evidences on the fact that the protective coating of the sample does not provide a necessary resistance under conditions of a powerful erosion flow. At the same time, some of the control samples placed under the same temperature conditions, but outside the flow zone, have preserved their integrity.

\section{CONCLUSIONS}

The erosion factor of the matrix and filler phase composition having influence on the $\mathrm{C}-\mathrm{C}$ composite resistance has been investigated.
The main mechanisms of such an effect are determined and the steps of improving the functional characteristics of composites are formulated.

It is shown that $\mathrm{C}-\mathrm{C}$ composites have a high potential, allowing them to endure significant chemical, thermal and mechanical loads, and can be applied in the rocket and space technology.

The erosion resistance of $\mathrm{C}-\mathrm{C}$ composites fabricated by the gas-phase infiltration method using the radiallymoving pyrolysis zone is due, first of all, to the highordered crystalline pyrocarbon matrix.

The efficiency of protective coatings for C-Ccomposite resistance is proved.

However, under conditions of simultaneous increased oxidation and erosion attack, the efficiency of protective coatings is insignificant.

In paper [7] it is proposed to use a three-layer coating to protect $\mathrm{C}-\mathrm{C}$ composites, each layer of which must perform its function. Such a multilayer coating provides the $\mathrm{C}-\mathrm{C}$ composite protection from the oxidation for more than $10 \mathrm{~h}$ at temperature of $1700{ }^{\circ} \mathrm{C}$ in the air.

\section{REFERENCES}

1. Structural materials based on graphite. M.: "Metallurgiya", 1971, N 6 (in Russian).

2. V.A. Gurin, V.F. Zelensky. Gas-phase methods for fabrication of carbon and carbon-carbon materials // Voprosy Atomnoj Nauki i Tekhniki. Series "Fizika Radiatsionnykh Povrezhdenij i Radiatsionnoye Materialovedeniye”. 1999, N 4(76), p. 13-31 (in Russian).

3. F.P. Sanin, E.A. Djur, A.F. Sanin, V.V. Khutorny. Kosmos $i$ Tekhnologii. Dnepropetrovsk: "ARTPress", 2007, 456 p. (in Russian).

4. V.F. Zelensky, V.A. Gurin, Yu.F. Konotop, N.P. Odejchuk. Graphit GSP // Voprosy Atomnoj Nauki $i$ Tekhniki Series "Fizika Radiatsionnykh Povrezhdenij $i$ Radiatsionnoye Materialovedeniye”. 1999, N 4(76), p. 67-78 (in Russian).

5. I.V. Gurin, V.A. Gurin, Yu.A. Gribanov, A.N. Bukolov, V.V. Gujda, A.A. Zavalishin. Obtaining laminate carbon-carbon materials and investigating their physical-mechanical properties // Voprosy Atomnoj Nauki i Tekhniki. Series "Vakuum, Chistye materialy, sverkhprovodniki”. 2016, N 1(10), p. 74-78 (in Russian).

6. M.B. Sazonova, I.B. Banyakovskaya, G.N. Gorbatov, V.N. Filippovich. Heat-resistant protective coatings for carbon materials // Neorganicheskiye Materialy. 1995, v. 75, N 2, p. 78-79 (in Russian).

7. V.I. Zmij, S.G. Ruden'kij, N.F. Kartsev, M.Yu. Bredikhin. Complex heat-resistant protective coatings for carbon-carbon materials // Fizika i Khimiya Stekla. 2009, v. 35, N 1, p. 58-63 (in Russian). 


\title{
ИССЛЕДОВАНИЕ ВЛИЯНИЯ ФАЗОВОГО СОСТАВА МАТРИЦЫ И НАПОЛНИТЕЛЯ НА ЭРОЗИОННУЮ СТОЙКОСТЬ УГЛЕРОД-УГЛЕРОДНЫХ КОМПОЗИЦИОННЫХ МАТЕРИАЛОВ, ПОЛУЧЕННЫХ МЕТОДОМ ГАЗОФАЗНОГО НАСЫЩЕНИЯ
}

\author{
Ю.А. Грибанов, И.В. Гурин, В.В. Гуйда, Ю.В. Гуйда
}

Показано влияние эрозионных факторов на фазовый состав углерод-углеродных композиционных материалов (УУКМ) (наполнитель и матрица). Определены основные механизмы влияния, сформулированы шаги повышения функциональных характеристик композитов. Предполагается, что эрозионная и сублимационная стойкости УУКМ, полученных методом газофазного насыщения с использованием радиально движущейся зоны пиролиза, обусловлены в первую очередь высокоупорядоченной кристаллической пироуглеродной матрицей. Показано, что УУКМ имеют уникальную температурную стойкость и работоспособность при высоких температурах.

\section{ДОСЛІДЖЕННЯ ВПЛИВУ ФАЗОВОГО СКЛАДУ МАТРИЦІ І НАПОВНЮВАЧА НА ЕРОЗІЙНУ СТІЙКІСТЬ ВУГЛЕЦЬ-ВУГЛЕЦЕВИХ КОМПОЗИЦІЙНИХ МАТЕРІАЛІВ, ЩО ОТРИМАНІ МЕТОДОМ ГАЗОФАЗНОГО НАСИЧЕННЯ}

\author{
Ю.О. Грибанов, І.В. Гурін, В.В. Гуйда, Ю.В. Гуйда
}

Показано вплив ерозійних факторів на фазовий склад вуглець-вуглецевих композиційних матеріалів (ВВКМ) (наповнювач і матриця). Визначено основні механізми впливу, сформульовані кроки підвищення функціональних характеристик композитів. Передбачається, що ерозійна та сублімаційна стійкісті ВВКМ, які отримані методом газофазного насичення 3 використанням зони піролізу, що радіально рухається, обумовлені в першу чергу високовпорядкованою кристалічною піровуглецевою матрицею. Показано, що ВВКМ має унікальну температурну стійкість і працездатність при високих температурах. 